\title{
Grape seed proanthocyanidin extract inhibits glutamate-induced cell death through inhibition of calcium signals and nitric oxide formation in cultured rat hippocampal neurons
}

Seo-Hee Ahn ${ }^{1,2}$, Hee Jung Kim³ ${ }^{3}$ Imju Jeong ${ }^{1,2}$, Yi Jae Hong ${ }^{1,2}$, Myung-Jun Kim', Duck-Joo Rhie', Yang-Hyeok Jo ${ }^{1}$, Sang June Hahn ${ }^{1}$ and Shin Hee Yoon ${ }^{1,2^{*}}$

\begin{abstract}
Background: Proanthocyanidin is a polyphenolic bioflavonoid with known antioxidant activity. Some flavonoids have a modulatory effect on $\left[\mathrm{Ca}^{2+}\right]_{i}$. Although proanthocyanidin extract from blueberries reportedly affects $\mathrm{Ca}^{2+}$ buffering capacity, there are no reports on the effects of proanthocyanidin on glutamate-induced $\left[\mathrm{Ca}^{2+}\right]_{\mathrm{i}}$ or cell death. In the present study, the effects of grape seed proanthocyanidin extract (GSPE) on glutamate-induced excitotoxicity was investigated through calcium signals and nitric oxide (NO) in cultured rat hippocampal neurons.

Results: Pretreatment with GSPE $(0.3-10 \mu \mathrm{g} / \mathrm{ml})$ for 5 min inhibited the $\left[\mathrm{Ca}^{2+}\right]_{i}$ increase normally induced by treatment with glutamate $(100 \mu \mathrm{M})$ for $1 \mathrm{~min}$, in a concentration-dependent manner. Pretreatment with GSPE (6 $\mu \mathrm{g} / \mathrm{ml}$ ) for 5 min significantly decreased the $\left[\mathrm{Ca}^{2+}\right]_{i}$ increase normally induced by two ionotropic glutamate receptor agonists, N-methyl-D-aspartate and alpha-amino-3-hydroxy-5-methyl-4-isoxazolepropionic acid (AMPA). GSPE further decreased AMPA-induced response in the presence of $1 \mu \mathrm{M}$ nimodipine. However, GSPE did not affect the $50 \mathrm{mM} \mathrm{K}$-induced increase in $\left[\mathrm{Ca}^{2+}\right]_{\mathrm{i}}$. GSPE significantly decreased the metabotropic glutamate receptor agonist (RS)-3,5-Dihydroxyphenylglycine-induced increase in $\left[\mathrm{Ca}^{2+}\right]_{\text {, }}$, but it did not affect caffeine-induced response.

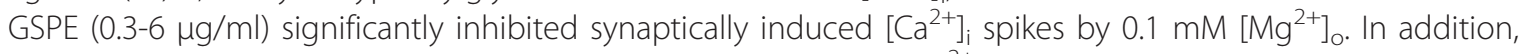
pretreatment with GSPE $(6 \mathrm{\mu g} / \mathrm{ml})$ for $5 \mathrm{~min}$ inhibited $0.1 \mathrm{mM}\left[\mathrm{Mg}^{2+}\right]_{0}$ - and glutamate-induced formation of NO. Treatment with GSPE $(6 \mu \mathrm{g} / \mathrm{ml})$ significantly inhibited $0.1 \mathrm{mM}\left[\mathrm{Mg}^{2+}\right]_{0}$ - and oxygen glucose deprivation-induced neuronal cell death.
\end{abstract}

Conclusions: All these data suggest that GSPE inhibits $0.1 \mathrm{mM}\left[\mathrm{Mg}^{2+}\right]_{0}$ - and oxygen glucose deprivation-induced neurotoxicity through inhibition of calcium signals and $\mathrm{NO}$ formation in cultured rat hippocampal neurons.

\section{Background}

Proanthocyanidins are polymers of flavonoid molecules that are widely available in fruits, vegetables, nuts, seeds, flowers, and bark, and especially in grape seeds [1]. These compounds possess a broad spectrum of antioxidative properties that provide potent protection against free radical-induced diseases, such as ischemia and reperfusion injury [2-4], aging [5], and carcinogenesis [6]. Proanthocyanidins are also known to possess

\footnotetext{
* Correspondence: s-hyoon@catholic.ac.kr

'Department of Physiology, College of Medicine, The Catholic University of Korea, 505 Banpo-dong, Seocho-gu, Seoul 137-701, Korea

Full list of author information is available at the end of the article
}

antibacterial, antiviral, anti-inflammatory, anti-allergic, and vasodilator properties $[1,7]$.

Glutamate is a major neurotransmitter in the central nervous system. Glutamate increases intracellular free $\mathrm{Ca}^{2+}$ concentration $\left(\left[\mathrm{Ca}^{2+}\right]_{\mathrm{i}}\right)$ in neurons by activating ionotropic and metabotropic glutamate receptors. In pathological conditions, including epilepsy and ischemia, a massive glutamate release leads to glutamate neurotoxicity $[8,9]$. The neurotoxicity is mainly due to $\mathrm{N}$ methyl-D-aspartate (NMDA) receptors, which cause excessive elevation of intracellular $\mathrm{Ca}^{2+}$ concentration $\left(\left[\mathrm{Ca}^{2+}\right]_{\mathrm{i}}\right)$ and subsequent neuronal cell death [10]. Elevation of $\left[\mathrm{Ca}^{2+}\right]_{\mathrm{i}}$ following NMDA receptor activation 
stimulates nitric oxide synthase (NOS), an enzyme that induces formation of nitric oxide (NO) in neurons [11]. NO reportedly also mediates glutamate neurotoxicity [12,13].

Some flavonoids have modulatory effects on $\left[\mathrm{Ca}^{2+}\right]_{\mathrm{i}}$. (-)-Epigallocatechine gallate (EGCG) increase $\left[\mathrm{Ca}^{2+}\right]_{i}$ in U87 cells [14] and inhibit glutamate-induced $\left[\mathrm{Ca}^{2+}\right]_{\mathrm{i}}$ increase in PC12 cells [15] and cultured rat hippocampal neurons [16]. Quercetin has stimulatory effects on voltage-dependent L-type $\mathrm{Ca}^{2+}$ channels in GH3 cells and inhibitory effects on L-type $\mathrm{Ca}^{2+}$ channels in NG108-15 cells [17]. In addition, EGCG [15], apigenin [18], and wogonin [19] have a neuroprotective effect in glutamate neurotoxicity. Proanthocyanidin extract from blueberries has reportedly reversed dopamine, $\mathrm{A} \beta_{42}$, and lipopolysaccharide-induced dysregulation of $\mathrm{Ca}^{2+}$ buffering capacity [20]. However, there are no reports on the effect of proanthocyanidin on glutamate-induced $\left[\mathrm{Ca}^{2+}\right]_{i}$ or cell death in cultured rat hippocampal neurons.

The present study determined whether grape seed proanthocyanidin extract (GSPE) affected glutamateinduced $\mathrm{Ca}^{2+}$ signalling and $\mathrm{NO}$ formation in cultured rat hippocampal neurons. It further examined whether GSPE protects neurons against neurotoxicity induced by low extracellular $\mathrm{Mg}^{2+}$ concentration $\left(\left[\mathrm{Mg}^{2+}\right]_{\mathrm{o}}\right)$ and oxygen glucose deprivation.

\section{Results}

\section{Effect of GSPE on glutamate-induced $\left[\mathrm{Ca}^{2+}\right]_{i}$ increase}

Since elevation of $\left[\mathrm{Ca}^{2+}\right]_{i}$ is one of the major causes of glutamate excitotoxicity [10], the present study first examined the effect of GSPE on glutamate-induced $\left[\mathrm{Ca}^{2}\right.$ $\left.{ }^{+}\right]_{\mathrm{i}}$ increase in cultured rat hippocampal neurons. Treatment with glutamate $(100 \mu \mathrm{M})$ for 1 min caused $\left[\mathrm{Ca}^{2+}\right]_{\mathrm{i}}$ increase. Reproducible response could be elicited by applying glutamate $(100 \mu \mathrm{M})$ for $1 \mathrm{~min}$ at 30 -min intervals (peak 2 /peak $1=97.6 \pm 2.4 \%, \mathrm{n}=27$ ) (Figure $1 \mathrm{~A}$ ). Pretreatment with GSPE $(0.3 \mu \mathrm{g} / \mathrm{ml})$ for $5 \mathrm{~min}$ did not affect the glutamate-induced $\left[\mathrm{Ca}^{2+}\right]_{\mathrm{i}}$ response (peak 2/ peak $1=100.8 \pm 3.8 \%, \mathrm{n}=15$ ) (Figure $1 \mathrm{~B})$. Pretreatment with higher concentrations of GSPE $(1-6 \mu \mathrm{g} / \mathrm{ml})$ inhibited the glutamate-induced response in a concentration-dependent manner (peak 2 /peak $1=92.0 \pm 2.1 \%$ at $1 \mu \mathrm{g} / \mathrm{ml}, \mathrm{n}=17 ; 86.5 \pm 3.5 \%$ at $3 \mu \mathrm{g} / \mathrm{ml}, \mathrm{n}=16 ; 71.9$ $\pm 2.3 \%$ at $6 \mu \mathrm{g} / \mathrm{ml}, \mathrm{n}=21$ ). However, pretreatment with $10 \mu \mathrm{g} / \mathrm{ml}$ GSPE did not further inhibit the glutamateinduced response (peak 2/peak $1=72.4 \pm 3.5 \%$ at 10 $\mu \mathrm{g} / \mathrm{ml}, \mathrm{n}=16$ ) (Figure $1 \mathrm{C}-\mathrm{G}$ ). Therefore, the present study used $6 \mu \mathrm{g} / \mathrm{ml}$ of GSPE to quantify the inhibition of agonist-induced $\left[\mathrm{Ca}^{2+}\right]_{\mathrm{i}}$ increase. The $6 \mu \mathrm{g} / \mathrm{ml}$ concentration of IHEA GSPE used in the present study was less than or equal to the serum levels of polyphenols after intake of grape seed proanthocyanidin extract in humans [21].
Effect of GSPE on ionotropic glutamate receptor agonistinduced $\left[\mathrm{Ca}^{2+}\right]_{i}$ increase

To determine how GSPE inhibits glutamate receptorinduced $\left[\mathrm{Ca}^{2+}\right]_{\mathrm{i}}$ increase, the present study used two ionotropic glutamate receptor agonists, alpha-amino-3hydroxy-5-methyl-4-isoxazolepropionic acid (AMPA) and NMDA. Application of AMPA increased $\left[\mathrm{Ca}^{2+}\right]_{\mathrm{i}}$ by activating AMPA/kainate channels and then voltagegated $\mathrm{Ca}^{2+}$ channels in neurons. Reproducible increase in $\left[\mathrm{Ca}^{2+}\right]_{\mathrm{i}}$ was induced by treatment with $(S)$-AMPA $(10$ $\mu \mathrm{M}$ ) for $1 \mathrm{~min}$ at 10 -min intervals (peak 2/peak $1=93.7$ $\pm 5.4 \%, \mathrm{n}=20)$. Pretreatment with GSPE $(6 \mu \mathrm{g} / \mathrm{ml})$ for 5 min significantly inhibited the AMPA-induced $\left[\mathrm{Ca}^{2+}\right]_{\mathrm{i}}$ response (peak 2 /peak $1=80.8 \pm 2.0 \%, \mathrm{n}=23, P<$ 0.05) (Figure 2A1-A3).

$\mathrm{Ca}^{2+}$-permeable AMPA receptors are expressed in hippocampal neurons early in development [22]. The present study tested whether proanthocyanin inhibits $\mathrm{Ca}^{2+}$-permeable AMPA-receptor-mediated $\mathrm{Ca}^{2+}$ influx. Pretreatment with nimodipine $(1 \mu \mathrm{M})$ for $5 \mathrm{~min}$ inhibited the AMPA-induced $\left[\mathrm{Ca}^{2+}\right]_{\mathrm{i}}$ response (peak 2/peak 1 $=40.2 \pm 4.8 \%, \mathrm{n}=11, P<0.01)$. Pretreatment with GSPE $(6 \mu \mathrm{g} / \mathrm{ml})$ for 5 min further inhibited AMPAinduced response in the presence of nimodipine $(1 \mu \mathrm{M})$ (peak $3 /$ peak $1=27.3 \pm 6.7 \%, \mathrm{n}=9, P<0.01$ ) (Figure 2B1-B3).

In addition, reproducible NMDA-induced $\left[\mathrm{Ca}^{2+}\right]_{\mathrm{i}}$ increase was induced by treatment with NMDA (100 $\mu \mathrm{M}$ ) for $1 \mathrm{~min}$ at 20 -min intervals (peak 2/peak $1=94.9$ $\pm 7.6 \%, \mathrm{n}=11)$. Pretreatment with GSPE $(6 \mu \mathrm{g} / \mathrm{ml})$ for 5 min also significantly inhibited NMDA-induced $\left[\mathrm{Ca}^{2+}\right]_{\mathrm{i}}$ response (peak $2 /$ peak $1=71.1 \pm 2.6 \%, \mathrm{n}=15, P<$ 0.05) (Figure 3).

\section{Effect of GSPE on high $\mathrm{K}^{+}$-induced $\left[\mathrm{Ca}^{2+}\right]_{\mathrm{i}}$ increase}

Binding glutamate to its AMPA receptors induced an influx of $\mathrm{Na}^{+}$(partly $\mathrm{Ca}^{2+}$ ) into neurons and depolarized the neurons. This depolarization induced secondary activation of voltage-gated $\mathrm{Ca}^{2+}$ channels [23]. To determine the effect of GSPE on glutamate-induced secondary activation of $\mathrm{Ca}^{2+}$ channels, the present study observed whether GSPE affects the depolarizationinduced $\left[\mathrm{Ca}^{2+}\right]_{\mathrm{i}}$ increase by $50 \mathrm{mM} \mathrm{K} \mathrm{K}^{+}$HEPES-HBSS (Figure 4). Reproducible $\left[\mathrm{Ca}^{2+}\right]_{\mathrm{i}}$ increase was induced by treatment for $1 \mathrm{~min}$ with $50 \mathrm{mM} \mathrm{K}{ }^{+}$HEPES-HBSS at 30 -min intervals (peak 2/peak $1=91.2 \pm 2.7 \%, \mathrm{n}=22$ ). Treatment with GSPE $(6 \mu \mathrm{g} / \mathrm{ml})$ for $5 \mathrm{~min}$ did not affect high $\mathrm{K}^{+}$-induced $\left[\mathrm{Ca}^{2+}\right]_{\mathrm{i}}$ response (peak 2 /peak $1=93.2$ $\pm 1.7 \%, \mathrm{n}=27, P>0.05$ ) (Figure 4 ).

\section{Effect of GSPE on metabotropic glutamate receptor agonist or caffeine-induced $\left[\mathrm{Ca}^{2+}\right]_{i}$ increase}

Group I metabotropic glutamate receptors, composed of mGluR1 and mGluR5, are exclusively expressed at 


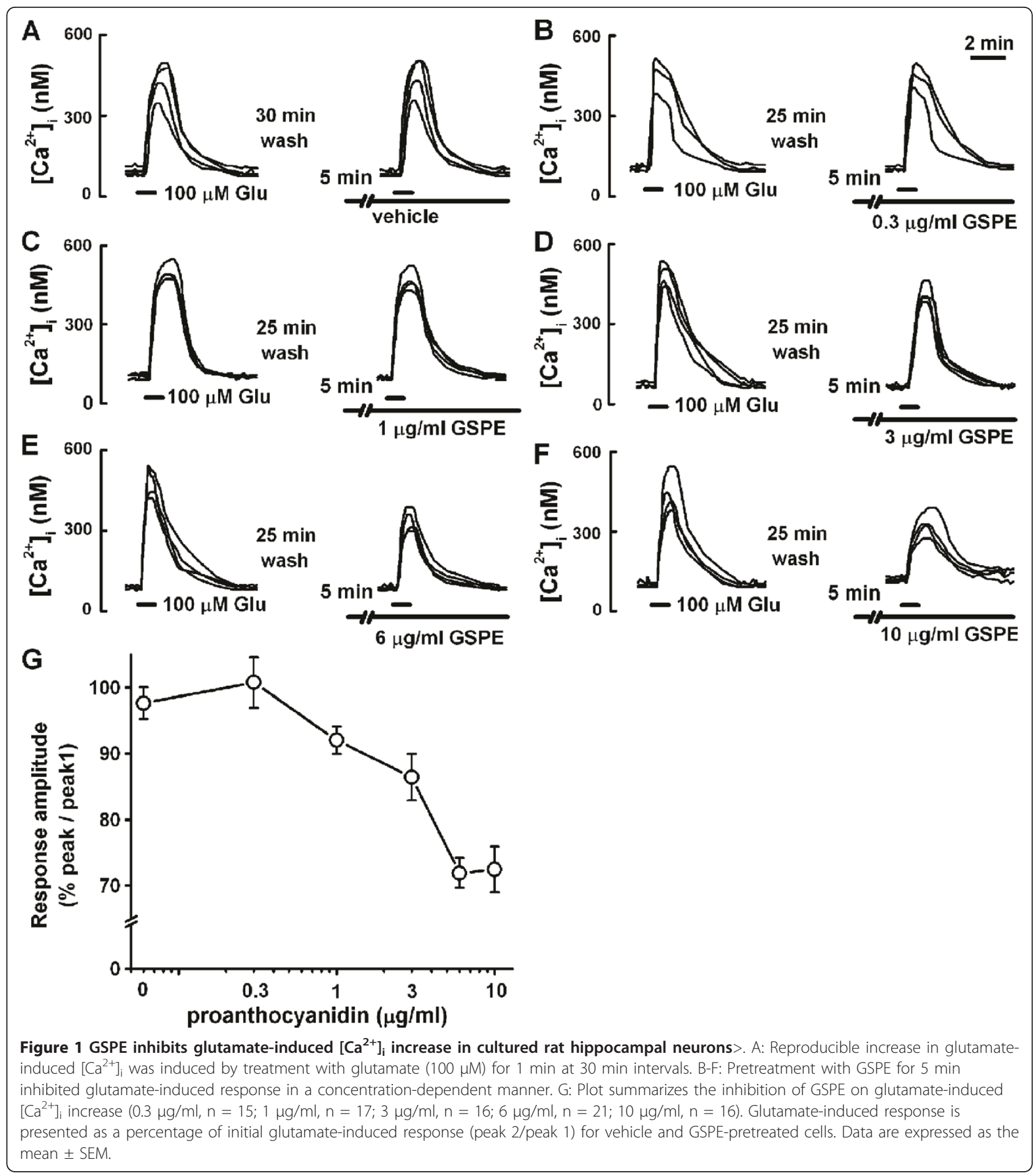

postsynaptic sites in the hippocampus [24]. They are linked to phosphatidylinositol metabolism and the formation of inositol 1,4,5-trisphosphate $\left(\mathrm{IP}_{3}\right)$ and diacylglycerol. Binding of $\mathrm{IP}_{3}$ to the $\mathrm{IP}_{3}$ receptors initiates release of $\mathrm{Ca}^{2+}$ from intracellular stores [25]. The present study examined whether GSPE affects the metabotropic glutamate receptor agonist response to DHPG-induced $\left[\mathrm{Ca}^{2+}\right]_{\mathrm{i}}$ increase. Reproducible $\left[\mathrm{Ca}^{2+}\right]_{\mathrm{i}}$ increase was induced by treatment with DHPG (100 $\mu \mathrm{M}$ ) for $1 \mathrm{~min}$ at 30 -min intervals (peak 2/peak $1=$ $105.9 \pm 1.3 \%, \mathrm{n}=31)$. Pretreatment with GSPE $(6 \mu \mathrm{g} /$ $\mathrm{ml}$ ) for 5 min significantly inhibited DHPG-induced 

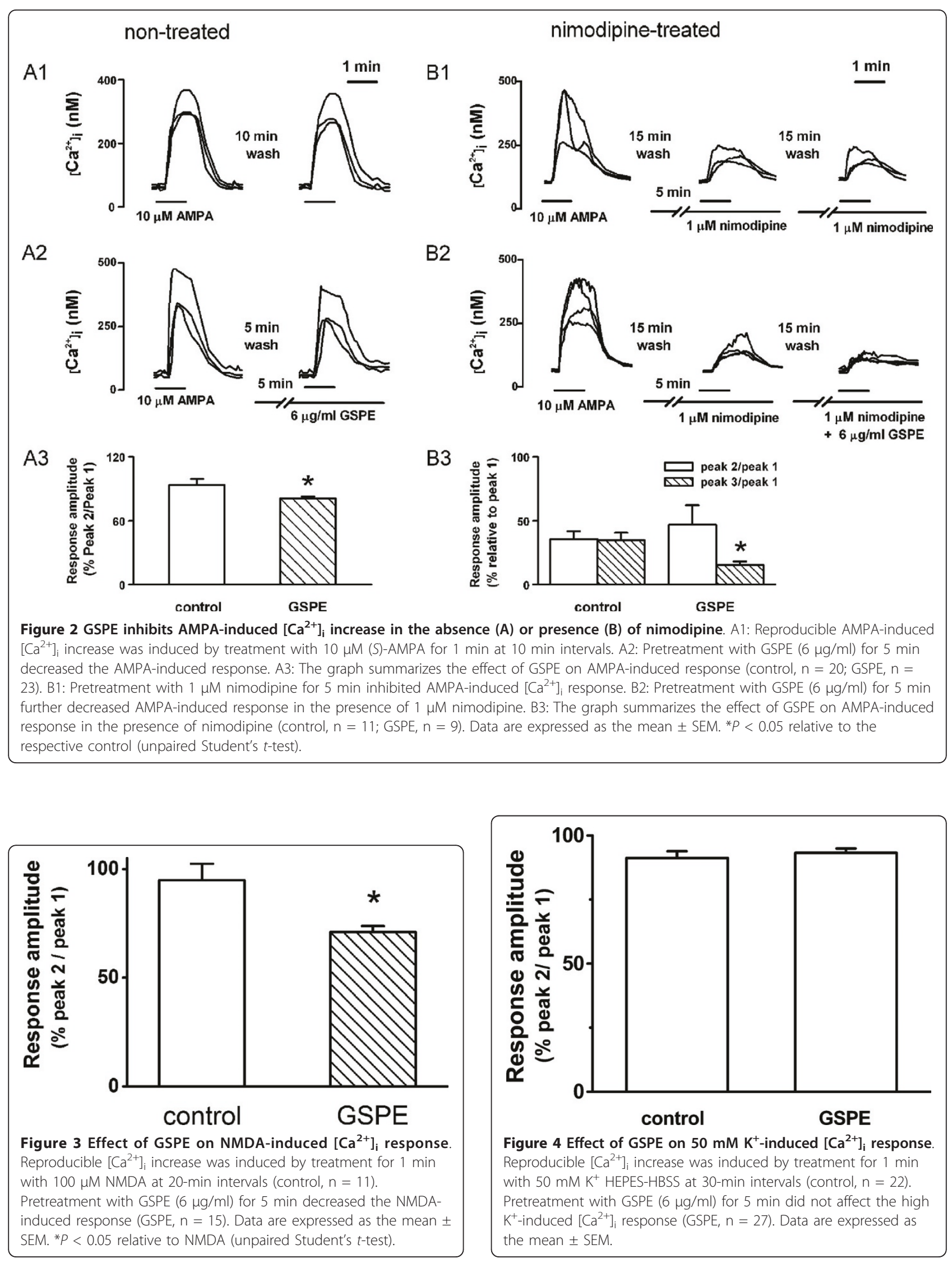
$\left[\mathrm{Ca}^{2+}\right]_{\mathrm{i}}$ response (peak 2/peak $1=68.9 \pm 1.8 \%, \mathrm{n}=29$, $P<0.05$ ) (Figure 5).

In addition to $\mathrm{IP}_{3}$ receptors, ryanodine receptors can mobilize intracellular $\mathrm{Ca}^{2+}$ stores [26]. Reproducible $\left[\mathrm{Ca}^{2+}\right]_{\mathrm{i}}$ increase was induced by treatment with caffeine $(10 \mathrm{mM})$ for $2 \mathrm{~min}$ at 10 -min intervals (peak $2 /$ peak $1=$ $98.8 \pm 1.0 \%$ of control response, $\mathrm{n}=14$ ). Pretreatment with GSPE $(6 \mu \mathrm{g} / \mathrm{ml})$ for $5 \mathrm{~min}$ did not significantly affect caffeine-induced $\left[\mathrm{Ca}^{2+}\right]_{\mathrm{i}}$ response $(92.5 \pm 2.4 \%$ of control response, $\mathrm{n}=9, \mathrm{P}>0.05$ ) (Figure 5).

Effect of GSPE on $0.1 \mathrm{mM}\left[\mathrm{Mg}^{2+}\right]_{0}$-induced $\left[\mathrm{Ca}^{2+}\right]_{\mathrm{i}}$ spikes The next study determined whether GSPE affects synaptically mediated $\left[\mathrm{Ca}^{2+}\right]_{\mathrm{i}}$ spikes. Previous studies have shown that reducing $\left[\mathrm{Mg}^{2+}\right]_{\mathrm{o}}$ to $0.1 \mathrm{mM}$ can elicit intense $\left[\mathrm{Ca}^{2+}\right]_{\mathrm{i}}$ spikes (Figure 6A) which depend on synaptic transmission [27]. $\left[\mathrm{Ca}^{2+}\right]_{\mathrm{i}}$ spikes were induced by $0.1 \mathrm{mM}\left[\mathrm{Mg}^{2+}\right]_{\mathrm{o}}$ in the cultured rat hippocampal neurons 13 days after plating. The low $\left[\mathrm{Mg}^{2+}\right]_{\mathrm{o}}$-induced $\left[\mathrm{Ca}^{2+}\right]_{\mathrm{i}}$ spikes gradually disappeared after treatment with GSPE $(6 \mu \mathrm{g} / \mathrm{ml})$. At $10 \mathrm{~min}$ after exposure to GSPE, the frequency of $\left[\mathrm{Ca}^{2+}\right]_{\mathrm{i}}$ spikes was $12.8 \pm 8.7 \%$ of the initial frequency (Figure 6B \&6C).

Effect of GSPE on $0.1 \mathrm{mM}\left[\mathrm{Mg}^{2+}\right]_{0}$-and glutamate-induced NO formation

$\mathrm{NO}$ is important for glutamate-induced neurotoxicity [12]. The present study determined whether GSPE affects low $\left[\mathrm{Mg}^{2+}\right]_{\mathrm{o}}$-induced $\mathrm{NO}$ formation using the

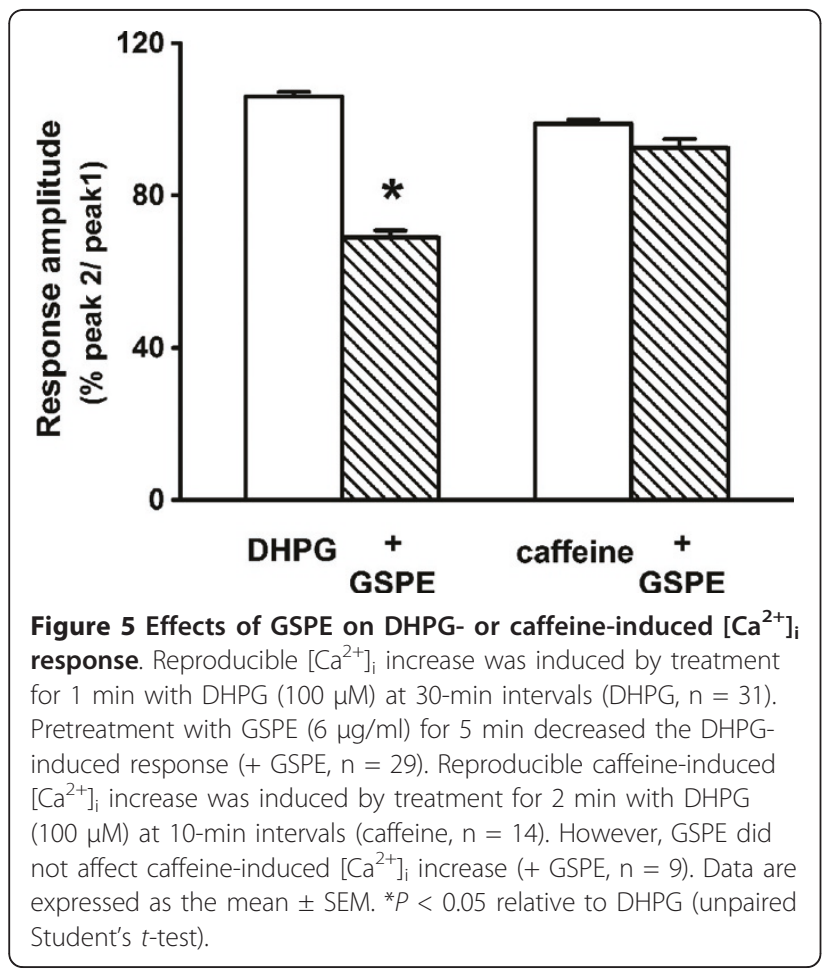

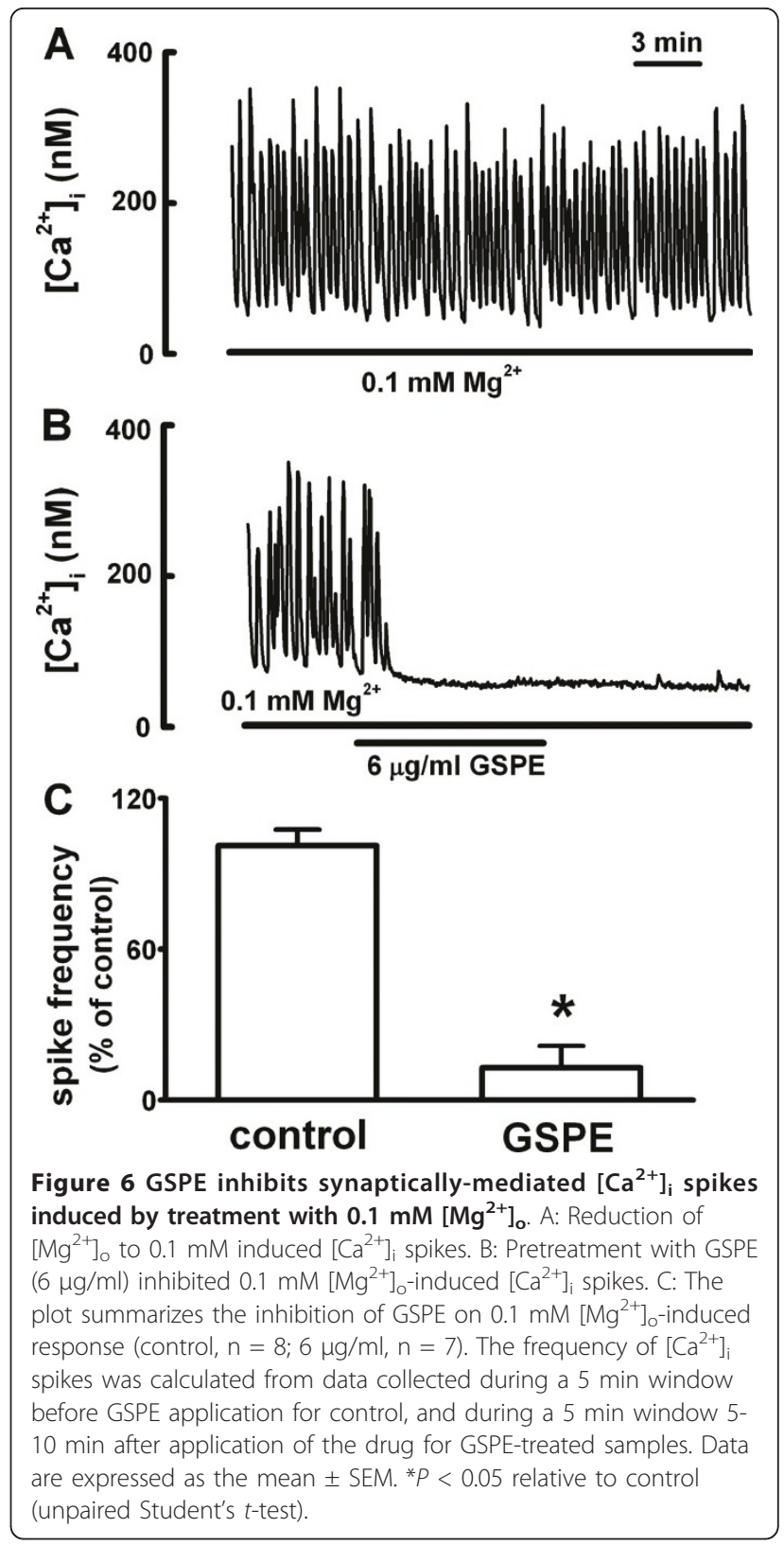

NO indicator DAF-2DA. Treatment with glutamate (100 $\mu \mathrm{M})$ or low $\left[\mathrm{Mg}^{2+}\right]_{\mathrm{o}}$ for $1 \mathrm{~h}$ significantly increased DAF2T fluorescence. While the $0.1 \mathrm{mM}\left[\mathrm{Mg}^{2+}\right]_{\mathrm{o}}$-induced increase in $\mathrm{NO}$ formation was markedly inhibited by pretreatment with GSPE $(6 \mu \mathrm{g} / \mathrm{ml})$ for $5 \mathrm{~min}$, and the glutamate-induced NO formation was slowly inhibited at a later phase (Figure 7A \&7B).

GSPE protects neuronal cells against $0.1 \mathrm{mM}\left[\mathrm{Mg}^{2+}\right]_{0}-$ and oxygen glucose deprivation-induced cell death

Reduction of $\left[\mathrm{Mg}^{2+}\right]_{\mathrm{o}}$ in the solution used to bathe cultured CNS neurons elicits an intense pattern of excitatory activity and $\left[\mathrm{Ca}^{2+}\right]_{\mathrm{i}}$ spikes and causes neuronal cell 

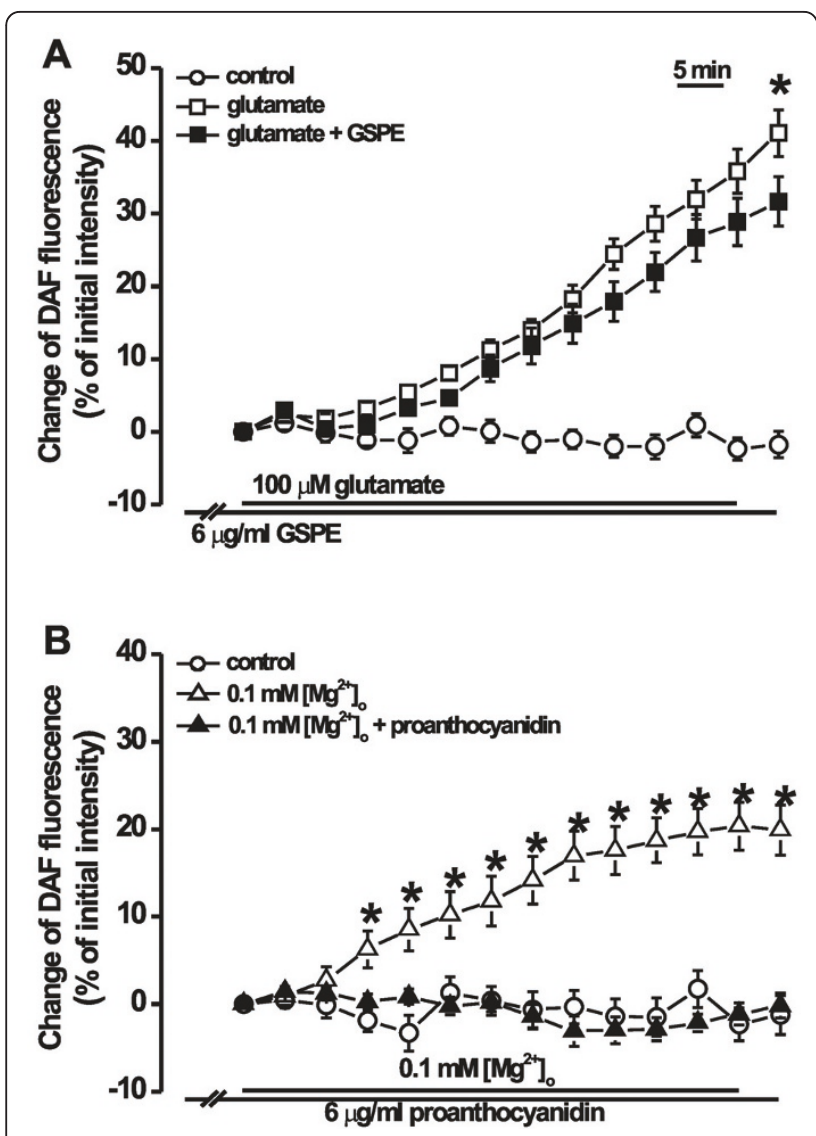

Figure 7 GSPE decreases glutamate- and $0.1 \mathrm{mM}\left[\mathrm{Mg}^{2+}\right]_{0}$ induced NO formation. Cells were preincubated with $20 \mu \mathrm{M}$ DAF2 DA for $60 \mathrm{~min}$. NO formation was shown as a percentage of the initial intensity of DAF-2T. Treatment with glutamate $(100 \mu \mathrm{M})$ or 0.1 $\mathrm{mM}\left[\mathrm{Mg}^{2+}\right]_{0}$ for $1 \mathrm{~h}$ significantly increased DAF-2T fluorescence. A: Pretreatment with GSPE $(6 \mu \mathrm{g} / \mathrm{ml})$ decreased the $100 \mu \mathrm{M}$ glutamateinduced NO formation $65 \mathrm{~min}$ after $100 \mu \mathrm{M}$ glutamate treatment (control, $\mathrm{n}=9 ; 100 \mu \mathrm{M}$ glutamate, $\mathrm{n}=13 ; 100 \mu \mathrm{M}$ glutamate +6 $\mu \mathrm{g} / \mathrm{ml} \mathrm{GSPE}, \mathrm{n}=12)$. ${ }^{*} P<0.05$ relative to $100 \mu \mathrm{M}$ glutamate (unpaired Student's $t$-test). B: Pretreatment with GSPE $(6 \mu \mathrm{g} / \mathrm{ml})$ decreased the $0.1 \mathrm{mM}\left[\mathrm{Mg}^{2+}\right]_{0}$-induced $\mathrm{NO}$ formation $15 \mathrm{~min}$ after $0.1 \mathrm{mM}\left[\mathrm{Mg}^{2+}\right]_{0}$ treatment (control, $\mathrm{n}=10 ; 0.1 \mathrm{mM}\left[\mathrm{Mg}^{2+}\right]_{0}, \mathrm{n}=14$; $0.1 \mathrm{mM}\left[\mathrm{Mg}^{2+}\right]_{0}+6 \mu \mathrm{g} / \mathrm{ml} \mathrm{GSPE}, \mathrm{n}=9$ ). Data are expressed as the mean \pm SEM. ${ }^{*} P<0.05$ relative to $0.1 \mathrm{mM}\left[\mathrm{Mg}^{2+}\right]_{0}$ (unpaired Student's t-test).

death [28-30]. The present study was an examination of whether GSPE protects cells against cell death induced by low $\left[\mathrm{Mg}^{2+}\right]_{\mathrm{o}}$. Cell viability was determined by counting the number of viable neurons before and 20-24 h after treatment (Figure 8 \& Figure 9A). In the control cells, cell survival was decreased slightly (Figure 8, data shown in Methods section). Reduction of $\left[\mathrm{Mg}^{2+}\right]_{0}$ markedly decreased neuronal cell survival $(52.6 \pm 0.9 \%$ of the control) (Figure 8 \& Figure 9A). A similar proportion of the GSPE-treated cells died relative to the control cells (Figure 8 \& Figure 9A). However, a $0.1 \mathrm{mM}\left[\mathrm{Mg}^{2+}\right]_{\mathrm{o}^{-}}$ induced decrease in cell survival was markedly inhibited by $6 \mu \mathrm{g} / \mathrm{ml}$ GSPE $(78.6 \pm 9.9 \%$ of control) (Figure $8 \&$ Figure 9A). The effect of GSPE on oxygen glucose deprivation-induced cell death was examined further (Figure 9B). The cells in glucose-free BSS, with and without GSPE $(6 \mu \mathrm{g} / \mathrm{ml})$, were gassed with $85 \% \mathrm{~N}_{2}, 10 \%$ $\mathrm{H}_{2}$, and $5 \% \mathrm{CO}_{2}$ for $90 \mathrm{~min}$, and then were regrown in DMEM supplemented with $10 \%$ horse serum and penicillin/streptomycin in a $\mathrm{CO}_{2}$ incubator for $24 \mathrm{~h}$. Oxygen glucose deprivation decreased neuronal cell survival to $57.8 \pm 2.2 \%$ of the control. However, treatment with GSPE $(6 \mu \mathrm{g} / \mathrm{ml})$ increased cell survival to $81.3 \pm 7.3 \%$ of the control.

\section{Discussion}

The present study used an in vitro rat hippocampal culture model to determine the inhibitory mechanisms of GSPE in low $\left[\mathrm{Mg}^{2+}\right]_{\mathrm{o}}$ or oxygen glucose deprivationinduced neuronal cell death. GSPE reduced the glutamate-induced $\left[\mathrm{Ca}^{2+}\right]_{\mathrm{i}}$ increase by inhibiting the AMPA, NMDA, and DHPG-induced $\left[\mathrm{Ca}^{2+}\right]_{\mathrm{i}}$ increase in hippocampal neurons. Synaptically mediated low $\left[\mathrm{Mg}^{2+}\right]_{\mathrm{o}^{-}}$ induced $\left[\mathrm{Ca}^{2+}\right]_{\mathrm{i}}$ spikes were also inhibited by GSPE. GSPE inhibited low $\left[\mathrm{Mg}^{2+}\right]_{\mathrm{o}}$ or oxygen glucose deprivation-induced neuronal cell death by inhibition of both $\left[\mathrm{Ca}^{2+}\right]_{\mathrm{i}}$ increase and $\mathrm{Ca}^{2+}$-dependent $\mathrm{NO}$ formation.

Glutamate depolarizes membranes by an influx of $\mathrm{Na}^{+}$ (partly $\mathrm{Ca}^{2+}$ ) through non-NMDA receptors, which secondarily activate voltage-gated $\mathrm{Ca}^{2+}$ channels and induce $\mathrm{Ca}^{2+}$ influx [23]. Glutamate also induces $\mathrm{Ca}^{2+}$ influx directly through NMDA receptor channels and $\mathrm{Ca}^{2}$ ${ }^{+}$-permeable non-NMDA AMPA receptor channels. In the present study, GSPE inhibited glutamate, AMPA, and NMDA-induced $\left[\mathrm{Ca}^{2+}\right]_{\mathrm{i}}$ increase, but it did not affect the depolarization-induced $\left[\mathrm{Ca}^{2+}\right]_{\mathrm{i}}$ increase from $50 \mathrm{mM} \mathrm{K}^{+}$HEPES-HBSS, suggesting that GSPE inhibits AMPA-induced $\left[\mathrm{Ca}^{2+}\right]_{\mathrm{i}}$ increase by inhibiting $\mathrm{Ca}^{2+}$ influx directly through $\mathrm{Ca}^{2+}$-permeable AMPA receptors. In fact, $\mathrm{Ca}^{2+}$-permeable AMPA receptors are strongly expressed in hippocampal neurons, especially early in development [22]. All these data suggested that GSPE inhibited $\mathrm{Ca}^{2+}$ influx through $\mathrm{Ca}^{2+}$-permeable AMPA channels and NMDA channels. This data are indirectly supported by other reports that flavonoids such as baicalin, baicalein, and EGCG, decreased glutamate or NMDA-induced $\left[\mathrm{Ca}^{2+}\right]_{\mathrm{i}}$ increase $[15,31]$.

The group I metabotropic glutamate receptor agonist, DHPG, induces a release of $\mathrm{Ca}^{2+}$ from $\mathrm{IP}_{3}$-sensitive stores by activating PLC $[25,32]$. In the present study, GSPE inhibited DHPG-induced $\left[\mathrm{Ca}^{2+}\right]_{\mathrm{i}}$ increase. Although the working mechanism of GSPE is not obvious, GSPE may inhibit DHPG-induced $\mathrm{Ca}^{2+}$ release from $\mathrm{IP}_{3}$-sensitive stores or DHPG-induced activation of PLC. Therefore, further research is needed to determine whether proanthocyanidin inhibits release of $\mathrm{Ca}^{2+}$ from 


\section{D14 D15}
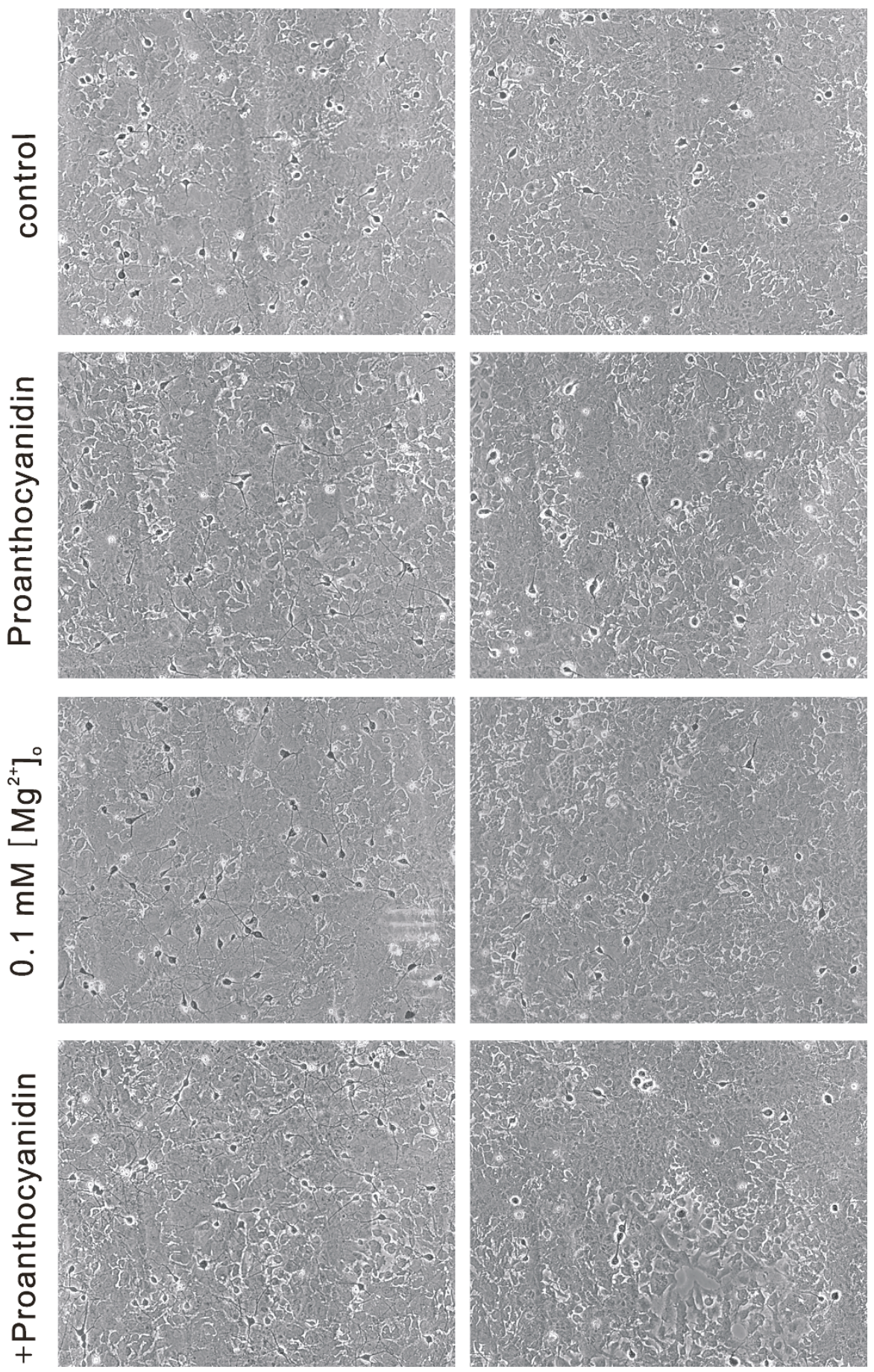

Figure $8 \mathrm{GSPE}$ protects cells against $0.1 \mathrm{mM}\left[\mathrm{Mg}^{2+}\right]_{0}$-induced neurotoxicity. Phase-contrast photomicrographs showed the same field of cultured rat hippocampal neurons before treatment (left, D14) and 20-24 h after treatment (right, D15). The cells were treated with normal medium (control), GSPE $(6 \mu \mathrm{g} / \mathrm{ml}), 0.1 \mathrm{mM}\left[\mathrm{Mg}^{2+}\right]_{\circ}$ and $0.1 \mathrm{mM}\left[\mathrm{Mg}^{2+}\right]_{\circ}$ plus GSPE (+ GSPE)-containing medium at 14 days in culture. Hippocampal neurons (identified by a light halo around the soma and long fine processes) grew on a bed of non-neuronal cells that formed a mosaic beneath them. 

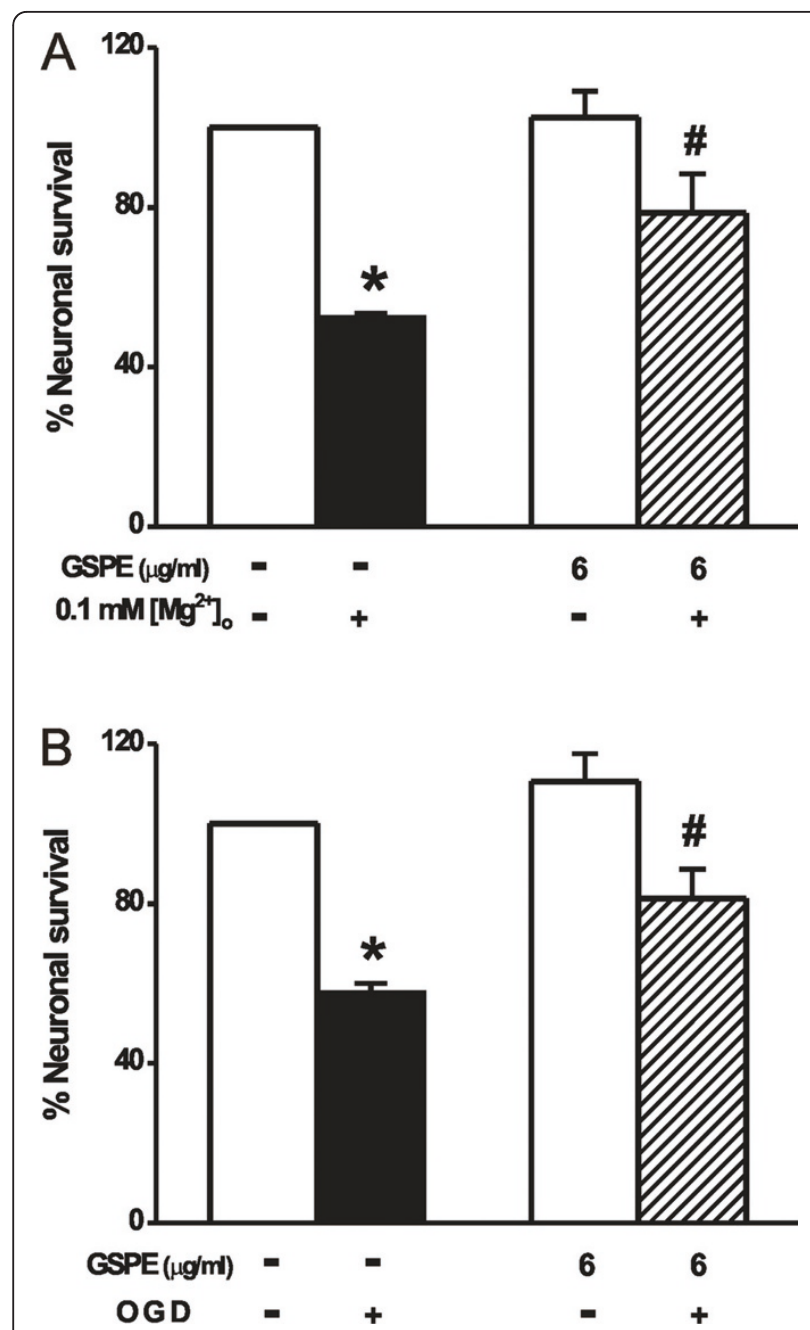

Figure 9 Effect of GSPE on $0.1 \mathrm{mM}\left[\mathrm{Mg}^{2+}\right]_{0}$ and oxygen glucose deprivation-induced neurotoxicity. A: Hippocampal neurons were exposed to normal medium or $0.1 \mathrm{mM}\left[\mathrm{Mg}^{2+}\right]_{0}$ containing medium with or without GSPE $(6 \mu \mathrm{g} / \mathrm{ml}, \mathrm{n}=8)$ for $20-24$ h. B: Hippocampal neurons were exposed to normal or oxygen glucose deprived conditions without GSPE $(O G D, n=8)$ or with GSPE $(6 \mu \mathrm{g} / \mathrm{ml}, \mathrm{n}=8)$ for $90 \mathrm{~min}$. After 20-24 h, the same fields of cells were recounted. Data are expressed as the mean \pm SEM. ${ }^{*} P<$ 0.001 relative to the control, \# $P<0.05$ relative to $0.1 \mathrm{mM}\left[\mathrm{Mg}^{2+}\right.$ 。 or OGD (ANOVA with Bonferroni's test).

$\mathrm{IP}_{3}$-sensitive stores or metabotropic glutamate receptorinduced activation of PLC.

In the present study, GSPE inhibited glutamateinduced $\left[\mathrm{Ca}^{2+}\right]_{\mathrm{i}}$ increase by inhibiting AMPA, NMDA, and metabotropic glutamate receptor-induced $\left[\mathrm{Ca}^{2+}\right]_{\mathrm{i}}$ increase. Reduction of $\left[\mathrm{Mg}^{2+}\right]_{\mathrm{o}}$ in cultured central nervous system neurons to $0.1 \mathrm{mM}$ elicited $\left[\mathrm{Ca}^{2+}\right]_{\mathrm{i}}$ spikes that depend on glutaminergic synaptic transmission $[27,29,33]$. In the present study, GSPE inhibited low $\left[\mathrm{Mg}^{2}\right.$ $\left.{ }^{+}\right]_{\mathrm{o}}$-induced $\left[\mathrm{Ca}^{2+}\right]_{\mathrm{i}}$ spikes. All these data suggest a possibility that proanthocyanidin can inhibit glutaminergic synaptic transmission in hippocampal neurons. In the present study, GSPE did not affect the depolarizationinduced $\left[\mathrm{Ca}^{2+}\right]_{\mathrm{i}}$ increase induced by high $\mathrm{K}^{+}$, which is involved in neurotransmitter release in the synaptic terminal. Thus, it is not clear whether proanthocyanidin inhibited synaptic transmission by decreasing glutamate release in presynaptic sites.

In the present study, GSPE completely inhibited low $\left[\mathrm{Mg}^{2+}\right]_{\mathrm{o}}$-induced NO formation, and it slightly inhibited glutamate-induced formation. GSPE reportedly has potent inhibitory action on $\mathrm{NO}$ production presumably through of the inhibition of $\mathrm{Ca}^{2+}$-dependent nitric oxide synthase [34]. In neuronal cells, NO was synthesized from $\mathrm{Ca}^{2+}$-dependent enzymes, neuronal nitric oxide synthase $[35,36]$. Therefore, the inhibition of excessive $\mathrm{Ca}^{2+}$ influx or $\mathrm{Ca}^{2+}$ release from intracellular stores and formation of NO by glutamate in the present study suggest that proanthocyanidin inhibits $\mathrm{NO}$ formation by inhibiting glutamate or low $\left[\mathrm{Mg}^{2+}\right]_{\mathrm{o}}$-induced $\left[\mathrm{Ca}^{2+}\right]_{\mathrm{i}}$ increase.

Previous investigations have reported that proanthocyanidin protects multiple target organs from drug- and chemical-induced toxicity. GSPE protects cells against acetaminophen-induced hepato- and nephrotoxicity, amiodarone-induced lung toxicity, doxorubicin-induced cardiotoxicity, and dimethylnitrosamine-induced spleenotoxicity [37]. GSPE inhibited 12-O-tetradecanoylphorbol-13-acetate and O-ethyl-S,S-dipropyl phosphorodithioate-induced brain neurotoxicity [2,37]. Grape seed extract has also been reported to reduce brain ischemic injury in gerbils [4,38] and rats [39], suggesting that the neuroprotective effects of proanthocyanidin are mediated by its antioxidant effects and antiapoptotic effects, respectively. However, there have been no reports on the underlying roles of calcium signalling or NO formation in proanthocyanidin-induced neuroprotection. GSPE inhibited low $\left[\mathrm{Mg}^{2+}\right]_{\mathrm{o}}$ - and oxygen glucose deprivation-induced neuronal cell death as well as both $\left[\mathrm{Ca}^{2+}\right]_{\mathrm{i}}$ increase and $\mathrm{Ca}^{2+}$-dependent $\mathrm{NO}$ formation. Ischemic insults have reportedly induced $\left[\mathrm{Ca}^{2+}\right]_{\mathrm{i}}$ increase and formation of $\mathrm{NO}$ in neurons $[10,12,40,41]$. In addition, proanthocyanidin blueberry extract is reported to have reversed dopamine, $A \beta_{42}$, and lipopolysaccharide-induced dysregulation of $\mathrm{Ca}^{2+}$ buffering capacity, thereby inducing neuroprotection in hippocampal neurons [20]. These results suggest that proanthocyanidin might inhibit ischemia-induced neuronal cell death by inhibiting glutamate-induced $\left[\mathrm{Ca}^{2+}\right]_{\mathrm{i}}$ signalling and NO formation as well as antioxidant effects and antiapoptotic effects.

The daily intake of proanthocyanidins may vary from tens to several hundred $\mathrm{mg} /$ day depending on diet [42]. Proanthocyanidins, especially oligomeric proanthocyanidins, are more easily absorbed and are present in blood 
after oral intake $[21,43]$. Catechin and epicatechin are reportedly bioavailable to the brain after ingestion of oligomeric proanthocyanidin [43], which suggests that oligomeric proanthocyanidins can cross the blood-brain barrier and affect neuronal cells. In fact, the IH636 grape seed proanthocyanidin extract (GSPE) used in the present study was composed of more than $73 \%$ oligomeric polyphenolic compounds including monomeric, dimeric, trimeric, and tetrameric proanthocyanidin [44]. Although the biological efficacy of GSPE has been studied previously in humans $[37,44]$, the bioavailablity of GSPE used in the present study remains unknown. However, it should be noted that this particular concentration of grape seed proanthocyanidin extract (GSPE) was less than or equal to the serum concentration in humans following intake of $200 \mathrm{mg} / \mathrm{kg}$ proanthocyanidins or oligomeric proanthocyanidins [21]. These data suggest a possibility that IH636 grape seed proanthocyanidin extract (GSPE) can induce neuroprotection after intake of oligomeric proanthocyanidin in humans as well as animals.

\section{Conclusions}

The results of the present study showed that IH636 grape seed proanthocyanidin extract protected neuronal cells against the low $\left[\mathrm{Mg}^{2+}\right]_{\mathrm{o}}$ - and oxygen glucose deprivation-induced neurotoxicity in cultured rat hippocampal neurons. The neuroprotective effects of proanthocyanidin might have been mediated by inhibition of glutamate-induced calcium signalling and NO formation. These results demonstrated that proanthocyanidin, and especially oligomeric polyphenolic compounds, may have future utility as neuroprotective agents or as supplements against glutamate excitotoxicity-related neurologic disorders such as epilepsy, traumatic brain injury, and ischemia.

\section{Methods}

\section{Materials}

Materials were purchased from the following companies: IH636 grape seed proanthocyanidin extract (GSPE) from InterHealth Nutraceuticals (Benicia, CA, USA); Dulbecco's modified Eagle's medium (DMEM) and fetal bovine serum (FBS) from Invitrogen (Carlsbad, CA, USA); fura2 acetoxymethyl ester (AM) from Molecular Probes (Eugene, OR, USA); 4,5-diaminofluorescein diacetate (DAF-2DA) from A.G. Scientific (San Diego, CA, USA); N-methyl-D-aspartate (NMDA), alpha-amino-3hydroxy-5-methyl-4-isoxazolepropionic acid (AMPA), (S)-3,5-dihydroxyphenylglycine (DHPG) and all other reagents from Sigma (St. Louis, MO, USA).

\section{Primary rat hippocampal cell culture}

Rat hippocampal neurons were grown in primary culture as previously described [45] with minor modifications. Adult maternal Sprague-Dawley rats (250-300 g) were used in the present study. All experimental procedures performed on the animals were conducted with the approval of the Catholic Ethics Committee of the Catholic University of Korea and were in accordance with the National Institutes of Health Guide for the Care and Use of Laboratory Animals (revised 1996). Fetuses were removed on embryonic day 17 from maternal rats anesthetized with urethane $(1.3 \mathrm{~g} /$ $\mathrm{kg}$ b.w., i.p.). Hippocampi were dissected and placed in $\mathrm{Ca}^{2+-}$ and $\mathrm{Mg}^{2+}$-free Hank's balanced salt solution, $\mathrm{pH}$ 7.4. Cells were dissociated by trituration through a $5-\mathrm{ml}$ pipette and then a flame-narrowed Pasteur pipette. Cells were pelleted and resuspended in Dulbecco's modified Eagle's medium (DMEM) without glutamine and supplemented with $10 \%$ fetal bovine serum and penicillin/ streptomycin $(100 \mathrm{U} / \mathrm{ml}$ and $100 \mu \mathrm{g} / \mathrm{ml}$, respectively). Dissociated cells were then plated at a density of 50,000 cells/well onto 25 -mm-round cover glasses that were coated with poly-L-lysine $(0.1 \mathrm{mg} / \mathrm{ml})$ and washed with $\mathrm{H}_{2} \mathrm{O}$. The cells were grown in a humidified atmosphere of $10 \% \mathrm{CO}_{2}-90 \%$ air $(\mathrm{pH} 7.4)$ at $37^{\circ} \mathrm{C}$. The medium was replaced $72-90 \mathrm{~h}$ after plating with DMEM supplemented with $10 \%$ horse serum and penicillin/streptomycin and fed every 7 days by exchange of $25 \%$ of the medium. The cells were cultured without mitotic inhibitors for a minimum of 12 days. The cells were used after 1415 days in culture. During this period, neurons developed extensive neuritic networks, and formed functional synapses.

\section{Digital $\left[\mathrm{Ca}^{2+}\right]_{\mathrm{i}}$ imaging}

To measure $\left[\mathrm{Ca}^{2+}\right]_{\mathrm{i}}$, hippocampal cells were incubated in $4 \mu \mathrm{M}$ fura-2 AM in HEPES-buffered Hank's salt solution (HHSS: $20 \mathrm{mM}$ HEPES, $137 \mathrm{mM} \mathrm{NaCl}, 1.3 \mathrm{mM} \mathrm{CaCl}_{2}$, $0.4 \mathrm{mM} \mathrm{MgSO}, 0.5 \mathrm{mM} \mathrm{MgCl} 2,0.4 \mathrm{mM} \mathrm{KH} \mathrm{KO}_{4}, 0.6$ $\mathrm{mM} \mathrm{Na} \mathrm{H}_{2} \mathrm{PO}_{4}, 3.0 \mathrm{mM} \mathrm{NaHCO}$, and $5.6 \mathrm{mM}$ glucose) containing $0.5 \%$ bovine serum albumin for $45 \mathrm{~min}$ at $37^{\circ}$ C. The cover glass was then mounted in a flow-through chamber that was superfused at a rate of $1.5 \mathrm{ml} / \mathrm{min}$. Digital calcium imaging was performed as described by Rhie et al. [46]. The chamber containing the fura-2loaded cells was mounted on the stage of an inverted microscope (Nikon TE300, Tokyo, Japan), and alternately excited at $340 \mathrm{~nm}$ and $380 \mathrm{~nm}$ by rapidly switching optical filters (10 $\mathrm{nm}$ band pass) mounted on a computer-controlled wheel (Lambda 10-2, Sutter Instruments Inc., Novato, CA, USA) placed between a $100 \mathrm{~W}$ Xe arc lamp and the epifluorescence port of the microscope. Excitation light was reflected from a dichroic mirror (400 $\mathrm{nm}$ for fura-2) through a $20 \times$ objective (Nikon; N.A. 0.5). Digital fluorescence images $(510 \mathrm{~nm}$, $40 \mathrm{~nm}$ band-pass) were collected with a computer-controlled, cooled, charge-coupled device camera $(1280 \times$ 
1035 binned to $256 \times 207$ pixels, Quantix, Photometrics, Tucson, AZ., USA). Image pairs were collected every 2$20 \mathrm{~s}$ using an Axon Imaging Work Bench 2.2 (Axon Instruments, Inc., Forster City, CA., USA); exposure to excitation light was $120 \mathrm{~ms}$ per image. $\left[\mathrm{Ca}^{2+}\right]_{\mathrm{i}}$ was calculated from the ratio of the background-subtracted digital images. Cells were delimited by producing a mask that contained pixel values above a certain threshold applied to the $380 \mathrm{~nm}$ image. Background images were collected at the beginning of each experiment after removing cells from another area to the coverslip. Autofluorescence from cells not loaded with the dye was less than $5 \%$ and thus not corrected. Ratio values were converted to free $\left[\mathrm{Ca}^{2+}\right]_{\mathrm{i}}$ by the equation $\left[\mathrm{Ca}^{2+}\right]_{\mathrm{i}}=\mathrm{K}_{\mathrm{d}} \beta(\mathrm{R}-$ $\left.\mathrm{R}_{\min }\right) /\left(\mathrm{R}_{\max }-\mathrm{R}\right)$, in which $R$ was the $340 / 380 \mathrm{~nm}$ fluorescence emission ratio and $K_{d}=224 \mathrm{nM}$ was the dissociation constant for fura-2. $R_{\min }, R_{\max }$, and $\beta$ was determined in ionomycin-permeabilized cells in calcium-free and saturated solutions $\left(R_{\min }=0.325, R_{\max }=\right.$ 9.23, $\beta=7.61$ ).

\section{$\left[\mathrm{Ca}^{2+}\right]_{\mathrm{i}}$ measurement using fura-2-based-photometry}

$\left[\mathrm{Ca}^{2+}\right]_{\mathrm{i}}$ spikes were measured using fura-2-based-microfluorimetry [45]. The chamber containing the fura-2loaded cells was mounted on an inverted microscope (Nikon S-100F, Nikon, Tokyo, Japan). For the excitation of fura-2, light from a $75 \mathrm{~W}$ Xe arc lamp (LPS-220, Photon Technology International, NJ, USA) was passed through band-pass filters (340/20 and 380/20 nm, respectively). Excitation light was reflected sequentially from a dichroic mirror $(400 \mathrm{~nm})$ through a $40 \times$ phase contrast oil immersion objective (Nikon, Tokyo, Japan). Emitted light was reflected through a $510 \mathrm{~nm}$ filter to a photomultiplier tube (Model 710, Photon Technology International, NJ, USA) operating in photon-counting mode. Recordings were defined spatially with a rectangular diaphragm (D-104C, Photon Technology International, NJ, USA). $\left[\mathrm{Ca}^{2+}\right]_{\mathrm{i}}$ spikes were induced by HHSS containing $0.1 \mathrm{mM} \mathrm{MgCl} 2$ and $10 \mu \mathrm{M}$ glycine. $\left[\mathrm{Ca}^{2+}\right]_{\mathrm{i}}$ was calibrated by the same method that was used for the digital $\left[\mathrm{Ca}^{2+}\right]_{\mathrm{i}}$ imaging. $\mathrm{R}_{\min }, \mathrm{R}_{\max }$, and $\beta$ were 0.86 , 14.89 , and 7.42, respectively.

\section{Measurement of nitric oxide (NO)}

To measure the formation of $\mathrm{NO}$, the cells were incubated in an NO indicator DAF-2DA $(20 \mu \mathrm{M})$ in HHSS without BSA for $60 \mathrm{~min}$ at $37^{\circ} \mathrm{C}$. After DAF-2DA loading, the cells were rinsed with HHSS for $10 \mathrm{~min}$ and placed in a flow-through chamber. DAF-2T (the fluorescent triazolofluorescein produced by NO and DAF-2 reaction) images were obtained through excitation at $480 \mathrm{~nm}$ and emission at $535 \mathrm{~nm} / 25 \mathrm{~nm}$ (DM $505 \mathrm{~nm}$ ) [47] after treatment with or without GSPE.

\section{Toxicity}

For toxicity experiments, cells were plated on microetched coverslips (Belco Biotechnology, Vineland, NJ, USA) and at least 100 neurons were counted. In 0.1 $\mathrm{mM} \mathrm{Mg}{ }^{2+}$ medium-induced excitotoxicity experiments, coverslips were exposed for $24 \mathrm{~h}$ to the $0.1 \mathrm{mM} \mathrm{Mg}^{2+}$ medium with or without GSPE at 14 days in culture. After 20-24 h, the same fields of cells were recounted. In oxygen glucose deprivation-induced excitotoxicity experiments) [48], cultures were washed 3 times with a balanced salt solution (BSS: $116 \mathrm{mM} \mathrm{NaCl}, 5.4 \mathrm{mM}$

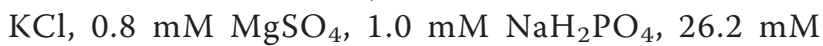
$\mathrm{NaHCO}_{3}, 1.8 \mathrm{mM} \mathrm{CaCl}$, and $10 \mathrm{mg} / \mathrm{L}$ phenol red) lacking glucose and were aerated with an anaerobic gas mix $\left(95 \% \mathrm{~N}_{2} / 5 \% \mathrm{CO}_{2}\right)$ for $10 \mathrm{~min}$ to remove residual oxygen, then were transferred to an anaerobic chamber (1025/ 1029 Anaerobic System, ThermoForma, Ohio, USA) containing a gas mixture of $5 \% \mathrm{CO}_{2}, 10 \% \mathrm{H}_{2}$, and $85 \%$ $\mathrm{N}_{2}$ for $90 \mathrm{~min}$. To terminate the oxygen glucose deprivation, cells were removed from the anaerobic chamber and then carefully washed with DMEM supplemented with $10 \%$ horse serum and penicillin/streptomycin. After 20-24 h, the same fields of cells were recounted.

Viable neurons were identified based on morphological criteria; they were phase-bright, had rounded somata, and extended long fine processes. Cell death was determined by comparing the number of viable neurons before and after treatment [30,49]. Viable neurons obtained were normalized and expressed as a percentage of sham-treated sister cultures (defined as 100\%). Control experiments showed that the loss of viable neurons assessed in this manner was proportional to the number of neurons damaged. In control cells (medium exchange only), $28.4 \pm 1.5 \%$ of the cells in the $0.1 \mathrm{mM} \mathrm{Mg}^{2+}$ experiment (Figure 8 ) and $27.3 \pm 1.2 \%$ of the cells in the OGD experiment died.

\section{Statistical analysis}

Data are expressed as the mean \pm SEM. Significance was determined using a Student's $t$-test or one-way analysis of variance (ANOVA) followed by a Bonferroni test.

\section{Lists of Abbreviations}

AM: acetoxymethyl ester; AMPA: alpha-amino-3hydroxy-5-methyl-4-isoxazolepropionic acid; $\left[\mathrm{Ca}^{2+}\right]_{\mathrm{i}}$ : intracellular free $\mathrm{Ca}^{2+}$ concentration; DAF-2DA: 4,5-diaminofluorescein diacetate; DHPG: $(R S)$-3,5-Dihydroxyphenylglycine; DMEM: Dulbecco's modified Eagle's medium; EGCG: (-)-epigallocatechine gallate; FBS: fetal bovine serum; GSPE: grape seed proanthocyanidin extract; HHSS: HEPES-buffered Hank's salt solution; IP3: inositol 1,4,5-trisphosphate; $\left[\mathrm{Mg}^{2+}\right]_{\mathrm{o}}$, extracellular $\mathrm{Mg}^{2+}$ concentration; NMDA: N-methyl-D-aspartate; 
NO: nitric oxide; NOS: nitric oxide synthase; OGD: oxygen glucose deprivation; PLC: phospholipase C

\section{Acknowledgements}

This research was supported by the Biogreen 21 Program (Code \#PJ007186), Rural Development Administration, Korea.

\section{Author details}

'Department of Physiology, College of Medicine, The Catholic University of Korea, 505 Banpo-dong, Seocho-gu, Seoul 137-701, Korea. ${ }^{2}$ the Catholic Institute for Advanced Biomaterials, The Catholic University of Korea, 505 Banpo-dong, Seocho-gu, Seoul 137-701, Korea. ${ }^{3}$ Department of Physiology, College of Medicine, Dankook University, San 29, Anseo-dong, Cheonan-si, Chungnam 330-714, Korea.

\section{Authors' contributions}

SHY designed the study. S-HA, HJK, IJ, YJ H, M-JK, D-JR and SJH performed the experiments and analyses. S-HA, HJK, Y-HJ, and SHY wrote the paper. All authors read and approved the final manuscript.

Received: 12 April 2011 Accepted: 3 August 2011

Published: 3 August 2011

\section{References}

1. Fine AM: Oligomeric proanthocyanidin complexes: history, structure, and phytopharmaceutical applications. Altern Med Rev 2000, 5:144-151.

2. Bagchi D, Garg A, Krohn RL, Bagchi M, Bagchi DJ, Balmoori J, Stohs SJ: Protective effects of grape seed proanthocyanidins and selected antioxidants against TPA-induced hepatic and brain lipid peroxidation and DNA fragmentation, and peritoneal macrophage activation in mice. Gen Pharmacol 1998, 30:771-776.

3. Roychowdhury S, Wolf G, Keilhoff G, Bagchi D, Horn T: Protection of primary glial cells by grape seed proanthocyanidin extract against nitrosative/oxidative stress. Nitric Oxide 2001, 5:137-149.

4. Wang Q, Sun AY, Simonyi A, Miller DK, Smith RE, Luchtefeld RG, Korthuis RJ, Sun GY: Oral administration of grape polyphenol extract ameliorates cerebral ischemia/reperfusion-induced neuronal damage and behavioral deficits in gerbils: comparison of pre- and post-ischemic administration. J Nutr Biochem 2009, 20:369-377.

5. Preuss HG, Bagchi D, Bagchi M: Protective effects of a novel niacin-bound chromium complex and a grape seed proanthocyanidin extract on advancing age and various aspects of syndrome X. Ann N Y Acad Sci 2002, 957:250-259

6. Mittal A, Elmets CA, Katiyar SK: Dietary feeding of proanthocyanidins from grape seeds prevents photocarcinogenesis in SKH-1 hairless mice: relationship to decreased fat and lipid peroxidation. Carcinogenesis 2003, 24:1379-1388.

7. Rice-Evans CA, Miller NJ, Paganga G: Structure-antioxidant activity relationships of flavonoids and phenolic acids. Free Radic Biol Med 1996, 20:933-956.

8. Choi DW, Maulucci-Gedde M, Kriegstein AR: Glutamate neurotoxicity in cortical cell culture. J Neurosci 1987, 7:357-368.

9. Lau A, Tymianski M: Glutamate receptors, neurotoxicity and neurodegeneration. Pflugers Arch 2010, 460:525-542.

10. Choi DW: lonic dependence of glutamate neurotoxicity. J Neurosci 1987 7:369-379.

11. Esplugues JV: $\mathrm{NO}$ as a signalling molecule in the nervous system. $\mathrm{Br} J$ Pharmacol 2002, 135:1079-1095.

12. Dawson VL, Dawson TM, London ED, Bredt DS, Snyder SH: Nitric oxide mediates glutamate neurotoxicity in primary cortical cultures. Proc Natl Acad Sci USA 1991, 88:6368-6371.

13. Lafon-Cazal M, Culcasi M, Gaven F, Pietri S, Bockaert J: Nitric oxide, superoxide and peroxynitrite: putative mediators of NMDA-induced cell death in cerebellar granule cells. Neuropharmacology 1993, 32:1259-1266.

14. Kim HJ, Yum KS, Sung JH, Rhie DJ, Kim MJ, Min do S, Hahn SJ, Kim MS Jo YH, Yoon SH: Epigallocatechin-3-gallate increases intracellular $\left[\mathrm{Ca}^{2+}\right] \mathrm{i}$ in U87 cells mainly by influx of extracellular $\mathrm{Ca}^{2+}$ and partly by release of intracellular stores. Naunyn Schmiedebergs Arch Pharmacol 2004, 369:260-267.
15. Lee JH, Song DK, Jung CH, Shin DH, Park J, Kwon TK, Jang BC, Mun KC, Kim SP, Suh SI, Bae JH: (-)-Epigallocatechin gallate attenuates glutamateinduced cytotoxicity via intracellular Ca modulation in PC12 cells. Clin Exp Pharmacol Physiol 2004, 31:530-536.

16. Han J-H, Kim KJ, Jang H-J, Jang JH, Kim M-J, Sung KW, Rhie D-J, Jo Y-H, Hahn SJ, Lee M-Y, Yoon SH: Effects of apigenin on glutamate-induced $\left[\mathrm{Ca}^{2+}\right]_{\mathrm{i}}$ increases in aultured rat hippocampal neurons. Kor J Physiol Pharmacol 2008, 12:43-50.

17. Wu SN, Chiang HT, Shen AY, Lo YK: Differential effects of quercetin, a natural polyphenolic flavonoid, on L-type calcium current in pituitary tumor (GH3) cells and neuronal NG108-15 cells. J Cell Physiol 2003, 195:298-308.

18. Losi G, Puia G, Garzon G, de Vuono MC, Baraldi M: Apigenin modulates GABAergic and glutamatergic transmission in cultured cortical neurons. Eur J Pharmacol 2004, 502:41-46.

19. Cho J, Lee HK: Wogonin inhibits excitotoxic and oxidative neuronal damage in primary cultured rat cortical cells. Eur J Pharmacol 2004, 485:105-110.

20. Joseph JA, Shukitt-Hale B, Brewer GJ, Weikel KA, Kalt W, Fisher DR: Differential protection among fractionated blueberry polyphenolic families against $D A-, A \beta_{42^{-}}$and LPS-induced decrements in $\mathrm{Ca}(2+)$ buffering in primary hippocampal cells. J Agric Food Chem 2010, 58:8196-8204

21. Fujii H, Sun B, Nishioka H, Hirose A, Aruoma Ol: Evaluation of the safety and toxicity of the oligomerized polyphenol Oligonol. Food Chem Toxicol 2007, 45:378-387.

22. Pickard L, Noel J, Henley JM, Collingridge GL, Molnar E: Developmental changes in synaptic AMPA and NMDA receptor distribution and AMPA receptor subunit composition in living hippocampal neurons. J Neurosc 2000, 20:7922-7931.

23. Gruol DL, Netzeband JG, Parsons $\mathrm{KL}: \mathrm{Ca}^{2+}$ signaling pathways linked to glutamate receptor activation in the somatic and dendritic regions of cultured cerebellar purkinje neurons. J Neurophysiol 1996, 76:3325-3340.

24. Lujan R, Nusser Z, Roberts JD, Shigemoto R, Somogyi P: Perisynaptic location of metabotropic glutamate receptors mGluR1 and mGluR5 on dendrites and dendritic spines in the rat hippocampus. Eur J Neurosci 1996, 8:1488-1500.

25. Conn PJ, Pin JP: Pharmacology and functions of metabotropic glutamate receptors. Annu Rev Pharmacol Toxicol 1997, 37:205-237.

26. Sandler VM, Barbara JG: Calcium-induced calcium release contributes to action potential-evoked calcium transients in hippocampal CA1 pyramidal neurons. J Neurosci 1999, 19:4325-4336.

27. Shen M, Piser TM, Seybold VS, Thayer SA: Cannabinoid receptor agonists inhibit glutamatergic synaptic transmission in rat hippocampal cultures. J Neurosci 1996, 16:4322-4334.

28. Abele AE, Scholz KP, Scholz WK, Miller RJ: Excitotoxicity induced by enhanced excitatory neurotransmission in cultured hippocampal pyramidal neurons. Neuron 1990, 4:413-419.

29. Rose $\mathrm{K}$, Christine CW, Choi DW: Magnesium removal induces paroxysmal neuronal firing and NMDA receptor-mediated neuronal degeneration in cortical cultures. Neurosci Lett 1990, 115:313-317.

30. Shen MX, Thayer SA: Cannabinoid receptor agonists protect cultured rat hippocampal neurons fom excitotoxicity. Mol Pharmacol 1998, 54:459-462.

31. Lee HH, Yang LL, Wang CC, Hu SY, Chang SF, Lee YH: Differential effects of natural polyphenols on neuronal survival in primary cultured central neurons against glutamate- and glucose deprivation-induced neuronal death. Brain Res 2003, 986:103-113.

32. Fagni $L$, Chavis $P$, Ango F, Bockaert J: Complex interactions between mGluRs, intracellular $\mathrm{Ca}^{2+}$ stores and ion channels in neurons. Trends Neurosci 2000, 23:80-88.

33. Abel A, Wittau N, Wieland T, Schultz G, Kalkbrenner F: Cell cycledependent coupling of the vasopressin V1a receptor to different $G$ proteins. J Biol Chem 2000, 275:32543-32551.

34. Kim YJ, Kim YA, Yokozawa T: Attenuation of oxidative stress and inflammation by gravinol in high glucose-exposed renal tubular epithelial cells. Toxicology 2010, 270:106-111.

35. Panda K, Ghosh S, Stuehr DJ: Calmodulin activates intersubunit electron transfer in the neuronal nitric-oxide synthase dimer. J Biol Chem 2001, 276:23349-23356. 
36. Rameau GA, Chiu LY, Ziff EB: Bidirectional regulation of neuronal nitricoxide synthase phosphorylation at serine 847 by the N-methyl-Daspartate receptor. J Biol Chem 2004, 279:14307-14314.

37. Bagchi D, Bagchi M, Stohs S, Ray SD, Sen CK, Preuss HG: Cellular protection with proanthocyanidins derived from grape seeds. Ann N Y Acad Sci 2002, 957:260-270

38. Hwang IK, Yoo KY, Kim DS, Jeong YK, Kim JD, Shin HK, Lim SS, Yoo ID, Kang TC, Kim DW, Moon WK, Won MH: Neuroprotective effects of grape seed extract on neuronal injury by inhibiting DNA damage in the gerbil hippocampus after transient forebrain ischemia. Life Sci 2004, 75:1989-2001

39. Feng Y, Liu YM, Leblanc MH, Bhatt AJ, Rhodes PG: Grape seed extract given three hours after injury suppresses lipid peroxidation and reduces hypoxic-ischemic brain injury in neonatal rats. Pediatr Res 2007, 61:295-300.

40. Silver IA, Erecinska M: Intracellular and extracellular changes of [Ca2+] in hypoxia and ischemia in rat brain in vivo. J Gen Physiol 1990, 95:837-866.

41. Tominaga T, Sato S, Ohnishi T, Ohnishi ST: Potentiation of nitric oxide formation following bilateral carotid occlusion and focal cerebral ischemia in the rat: in vivo detection of the nitric oxide radical by electron paramagnetic resonance spin trapping. Brain Res 1993, 614:342-346.

42. Santos-Buelga C, Scalbert A: Proanthocyanidins and tannin-like compounds - nature, occurrence, dietary intake and effects on nutrition and health. Journal of the Science of Food and Agriculture 2000, 80:1094-1117.

43. Prasain JK, Peng N, Dai Y, Moore R, Arabshahi A, Wilson L, Barnes S, Michael Wyss J, Kim H, Watts RL: Liquid chromatography tandem mass spectrometry identification of proanthocyanidins in rat plasma after oral administration of grape seed extract. Phytomedicine 2009, 16:233-243.

44. Bagchi D, Bagchi M, Stohs SJ, Das DK, Ray SD, Kuszynski CA, Joshi SS, Pruess HG: Free radicals and grape seed proanthocyanidin extract: importance in human health and disease prevention. Toxicology 2000, 148:187-197.

45. Shim EY, Kim HJ, Kim MJ, Rhie DJ, Jo YH, Kim MS, Hahn JS, Lee MY, Yoon SH: Desensitization of somatostatin-induced inhibition of low extracellular magnesium concentration-induced calcium spikes in cultured rat hippocampal neurons. Brain Res 2006, 1111:61-71

46. Rhie D-J, Sung J-H, Kim HJ, Ha U-S, Min DS, Kim M-S, Jo Y-H, Hahn SJ, Yoon SH: Endogenous somatostatin receptors mobilize calcium from inositol 1,4,5-trisphosphate-sensitive stores in NG108-15 cells. Brain Res 2003, 975:120-128.

47. Kojima H, Urano Y, Kikuchi K, Higuchi T, Hirata Y, Nagano T: Fluorescent Indicators for Imaging Nitric Oxide Production. Angew Chem Int Ed Engl 1999, 38:3209-3212.

48. Goldberg MP, Choi DW: Combined oxygen and glucose deprivation in cortical cell culture: calcium-dependent and calcium-independent mechanisms of neuronal injury. J Neurosci 1993, 13:3510-3524.

49. Moore AN, Kampfl AW, Zhao X, Hayes RL, Dash PK: Sphingosine-1phosphate induces apoptosis of cultured hippocampal neurons that requires protein phosphatases and activator protein-1 complexes. Neuroscience 1999, 94:405-415.

\section{doi:10.1186/1471-2202-12-78}

Cite this article as: Ahn et al:: Grape seed proanthocyanidin extract inhibits glutamate-induced cell death through inhibition of calcium signals and nitric oxide formation in cultured rat hippocampal neurons. BMC Neuroscience 2011 12:78.

\section{Submit your next manuscript to BioMed Central and take full advantage of:}

- Convenient online submission

- Thorough peer review

- No space constraints or color figure charges

- Immediate publication on acceptance

- Inclusion in PubMed, CAS, Scopus and Google Scholar

- Research which is freely available for redistribution

Submit your manuscript at www.biomedcentral.com/submit
Biomed Central 